\title{
Use of a lacZ Gene Fusion to Determine the Dependence Pattern and the Spore Compartment Expression of Sporulation Operon spoVA in spo Mutants of Bacillus subtilis
}

\author{
By JEFF ERRINGTON* AND JOEL MANDELSTAM \\ Microbiology Unit, Department of Biochemistry, University of Oxford, South Parks Road, \\ Oxford $O X 13 Q U, U K$
}

(Received 11 March 1986; revised 5 June 1986)

\begin{abstract}
A $\operatorname{spoVAA}:$ : lac $Z$ gene fusion has been used to study expression of the $\operatorname{spo} V A$ operon during sporulation in Bacillus subtilis. $\beta$-Galactosidase activity, encoded by the fusion gene, begins to be produced about $2.5 \mathrm{~h}$ after the induction of sporulation, well before the phenotypic consequences of spoVA mutations are manifested. spoVA expression is dependent on all of the known spoO and spoII loci and on some of the "early" spoIII loci, but not on 'later' loci. Several lines of evidence suggest that spoVA expression occurs only in the spore compartment. The implications of this observation for models of the overall regulation of gene expression during sporulation are discussed.
\end{abstract}

\section{INTRODUCTION}

The sporulation operon spoVA is one of more than 50 known genetic loci specifically concerned with the regulation of sporulation in Bacillus subtilis (Hranueli et al., 1974; Piggot \& Coote, 1976; Piggot et al., 1981). In addition to the single mutation that first defined the locus (89; Hranueli et al., 1974), seven further spoVA mutations have been isolated following directed mutagenesis of the lys- $I$ region of the $B$. subtilis chromosome (Errington \& Mandelstam, 1984). The locus has been cloned (Savva \& Mandelstam, 1984; Errington, 1984) and sequenced (Fort \& Errington, 1985) and the sequence indicates the existence of at least five genes, designated $A, B$, $C, D$ and $E$, which are transcribed as a single polycistronic mRNA (Fort \& Errington, 1985; Savva \& Mandelstam, 1985, 1986). An extensive region of homology between genes $C$ and $E$ suggests that one of them may have arisen by gene duplication (Errington et al., 1985). Complementation analysis of eight spoVA mutations indicates that they fall into four different genes. A mutation in any one of these genes causes sporulation to be blocked at a late stage. spoVA mutants synthesize alkaline phosphatase and glucose dehydrogenase (stage II and stage III marker events respectively) but not dipicolinic acid, which normally appears during stage V. Although the phase-grey spores which they produce are sensitive to heat and to chloroform, they are partially resistant to toluene and to lysozyme (Errington \& Mandelstam, 1984). Lencastre \& Piggot (1979) obtained genetic evidence indicating that the spoVA locus might be expressed in the spore compartment of the sporulating cell. Other groups have also suggested that certain gene products have a differential compartmental distribution (Andreoli et al., 1975; Nakayama et al., 1981). These findings raise the possibility that during sporulation there may be independent sequences of gene expression in the spore and in the mother-cell; these cells have different developmental fates and are separated initially by a double membrane and later by additional cortical and coat layers.

This paper describes the use of a spoVA : $l a c Z$ gene fusion, constructed as described in an accompanying paper (Errington, 1986), to analyse expression of the spoVA locus during sporulation. An analysis of the effects of mutations at other spo loci has been used to investigate 


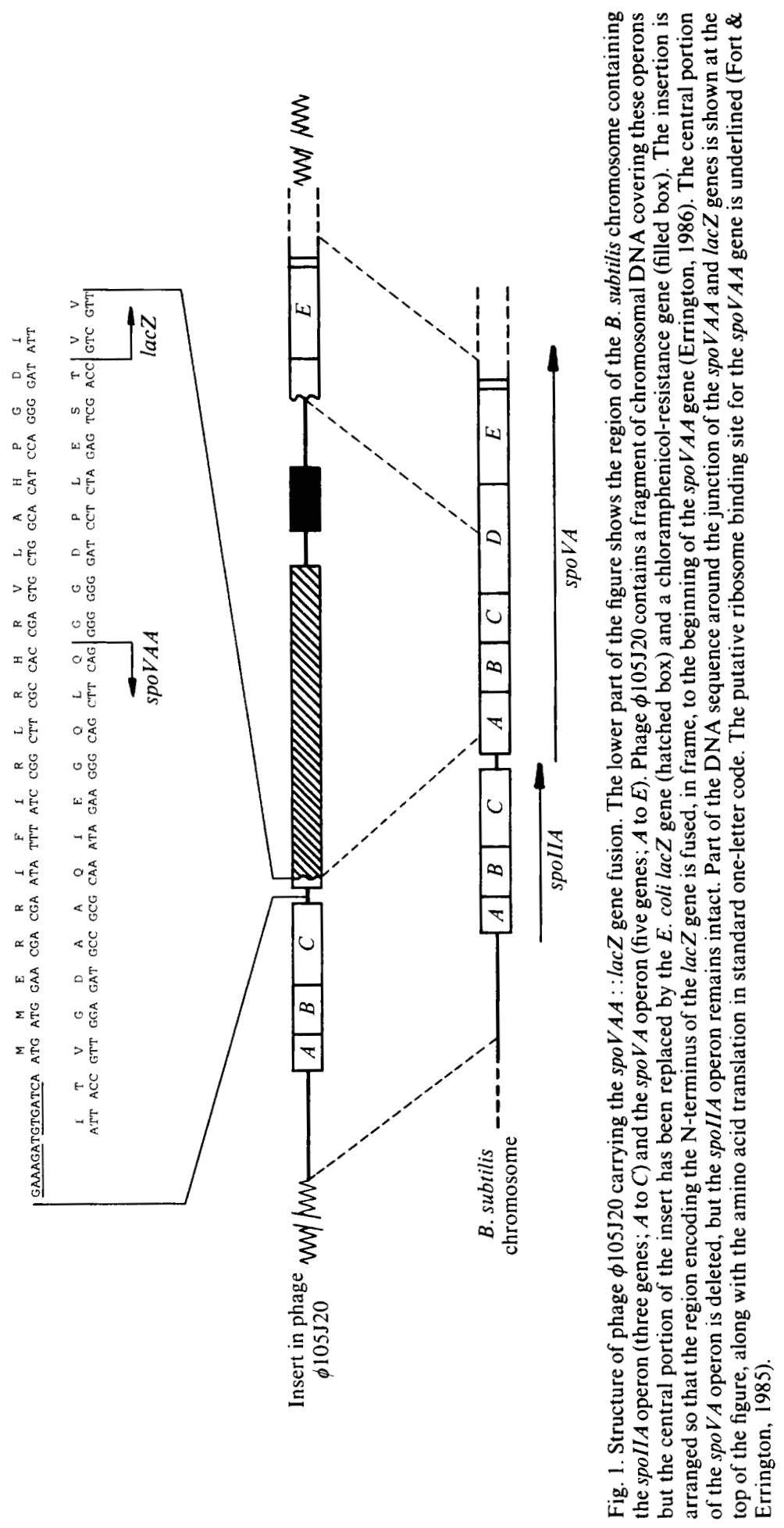


Table 1. Bacillus subtilis strains

\begin{tabular}{|c|c|c|}
\hline Strain & Genotype* & Origin \\
\hline $\begin{array}{l}4\left(\mathrm{Spo}^{-}\right) \\
337\left(\mathrm{Spo}^{+}\right)\end{array}$ & $\begin{array}{l}\text { lys-1 metC3 tal-1 spoVAA : :lacZ-cat } \\
\text { lys-1 metC3 tal-1 }(\phi 105 \mathrm{~J} 20 \\
\left.\text { spoIIA }{ }^{+} \text {spoVAA : :lacZ-cat }\right)\end{array}$ & Errington (1986) \\
\hline $4.1\left(\mathrm{Spo}^{-}\right)$ & $\operatorname{trpC2}$ spoVAA : :lacZ-cat & $\begin{array}{l}\text { Transformation of strain SG38 with } \\
\text { DNA from strain } 614 \text { and selection } \\
\text { for } \\
\text { Cm }^{R}\end{array}$ \\
\hline
\end{tabular}

* tal-1, resistance to $\beta$-thienylalanine; cat, resistance to chloramphenicol.

the genetic control of the spoVA locus, and accompanying papers deal with similar analyses of the spoIIA locus (Errington \& Mandelstam, 1986) and the spoIID locus (Clarke et al., 1986).

\section{METHODS}

Bacterial strains. These are listed in Table 1, except for the $\mathrm{Spo}^{+}$and $\mathrm{Spo}^{-}$strains listed in Table 1 of the preceding paper (Errington \& Mandelstam, 1986).

General methods. Media, techniques for growth and sporulation, transformation, transduction and $\beta$ galactosidase assays using 4-methylumbelliferyl- $\beta$-D-galactopyranoside (MUG) are all detailed in the preceding paper (Errington \& Mandelstam, 1986). One unit of $\beta$-galactosidase catalyses the production of $1 \mathrm{nmol} \mathrm{4-}$ methylumbelliferone $\min ^{-1}$ at $30^{\circ} \mathrm{C}$ using the standard assay described.

spoVAA::lac $Z$ gene fusion. An accompanying paper (Errington, 1986) describes the construction of a chromosomal spoVAA : :lac $Z$ fusion and a transducing phage $\phi 105 \mathrm{~J} 20$. The latter can be used to transfer the spoVA regulatory sequences and gene fusion to other bacterial strains by transduction followed by selection for chloramphenicol resistance. The structure of the DNA insert in this phage is shown in Fig. 1. The hybrid gene consists of the first 35 codons of the spoVAA gene, followed by an eight codon spacer region of 'synthetic' origin, and then all but the first eight codons of the lac $Z$ gene (Kalnins et al., 1983).

$\beta$-Galactosidase distribution in mother cell and forespore fractions. Samples $(50 \mathrm{ml})$ of sporulating cultures were harvested by centrifugation, washed in ice-cold Tris/ $\mathrm{HCl}$ buffer $\left(50 \mathrm{mM}, \mathrm{pH} \mathrm{7.5)}\right.$ and frozen at $-70^{\circ} \mathrm{C}$. The thawed pellet was resuspended in $10 \mathrm{ml}$ sodium phosphate buffer $(0.1 \mathrm{M}, \mathrm{pH} 7.0)$. A $4 \mathrm{ml}$ portion of the cell suspension was passed twice through a French pressure cell at $83 \mathrm{MPa}$, which released $>90 \%$ of the spores from their mother cells (Jenkinson et al., 1981). All but $1 \mathrm{ml}$ of the suspension was then centrifuged at low speed $(800 \mathrm{~g}$, $4 \mathrm{~min}$ ) to harvest the spores, and the supernatant ('mother cell' fraction) was carefully decanted. The spores were washed and resuspended in $3 \mathrm{ml}$ sodium phosphate buffer. Samples $(1 \mathrm{ml})$ of the whole cell suspension, both before and after French press treatment, and of the 'spore' and 'mother cell' fractions were then divided into two $0.5 \mathrm{ml}$ portions. To one portion of each type was added $0.5 \mathrm{ml}$ sodium phosphate buffer ('- germinant'); to the other ('+ germinant') was added $0.5 \mathrm{ml}$ sodium phosphate buffer containing L-alanine $(20 \mathrm{mM}), \mathrm{KCl}(60 \mathrm{mM}), \mathrm{D}$ glucose $(20 \mathrm{mM})$ and $\mathrm{D}$-fructose $(20 \mathrm{mM})$. The spore suspensions were incubated at $37^{\circ} \mathrm{C}$ for $1 \mathrm{~h}$ to allow germination to occur and $\beta$-galactosidase was determined by the MUG assay (Errington \& Mandelstam, 1986).

Preparation of spore coat proteins. Preparation of spores and of spore coat fractions, and extraction of spore coat proteins have been described in detail by Jenkinson $e$ t al. (1981).

$S D S-P A G E$. Spore coat proteins were electrophoresed on $1.5 \mathrm{~mm}$ thick polyacrylamide slab gels $(15 \%, \mathrm{w} / \mathrm{v})$ using the discontinuous buffer system of Laemmli \& Favre (1973) as described by Hames (1981). Protein bands were then stained with Coomassie brilliant blue R250 as described by Jenkinson et al. (1981). Molecular mass reference proteins (Pharmacia) were as follows: phosphorylase b (94000), bovine serum albumin (67000), ovalbumin (43000), carbonic anhydrase (30000), soybean trypsin inhibitor (20100) and $\alpha$-lactalbumin (14400).

\section{RESULTS}

Time of expression of spoVAA : : lacZ during sporulation

The time course for $\beta$-galactosidase synthesis under sporulation conditions was similar in strains carrying the gene fusion in the chromosomal location (strain 614; phenotypically $\mathrm{SpoVA}^{-}$) or on the $\phi 105 \mathrm{~J} 20$ prophage (strain SG37; phenotypically $\mathrm{Spo}^{+}$). Activity began to appear at about $t_{2 \cdot 5}$, reached a peak at $t_{4}$ or $t_{5}$ and then declined towards the background level (Fig. 2). The amount of activity in a strain, MB75, with no lacZ fusion was insignificant. 


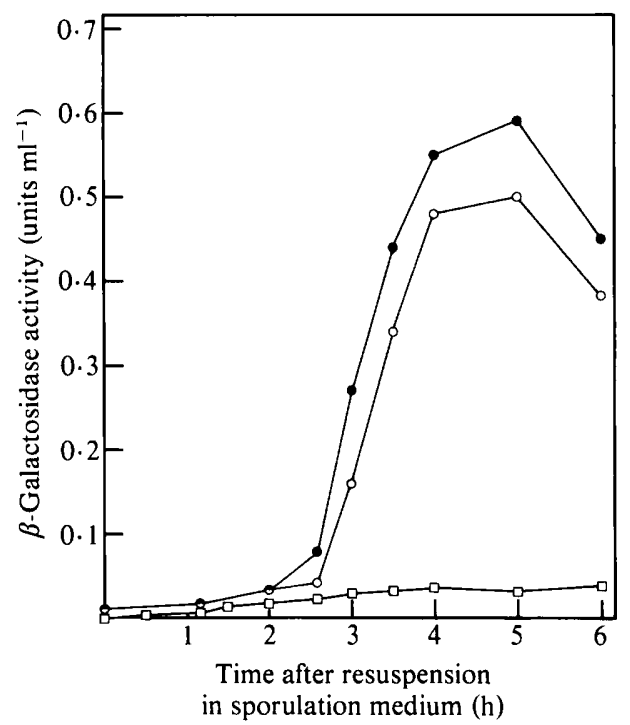

Fig. 2

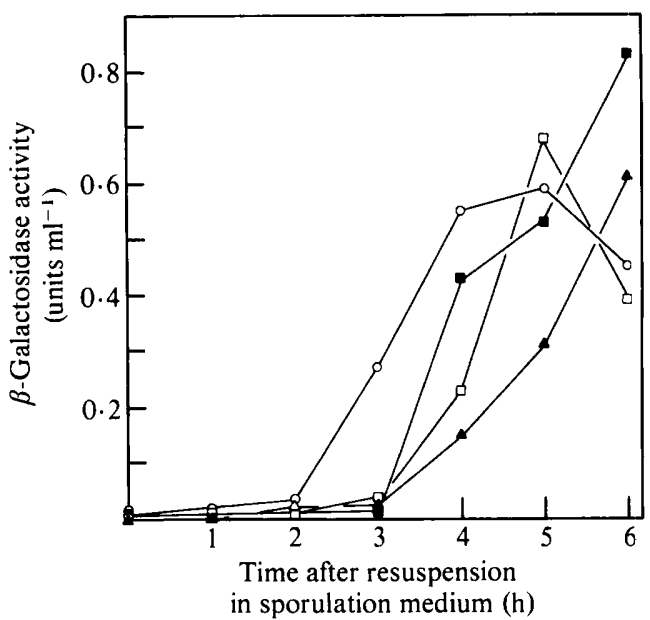

Fig. 3

Fig. 2. $\beta$-Galactosidase production during sporulation by strains carrying a spoVAA : : lac $Z$ gene fusion. Strains MB75 ( $\square), 614(\bigcirc)$ and SG37 (O) were induced to sporulate and at intervals samples were taken and assayed for $\beta$-galactosidase as described in Methods.

Fig. 3. $\beta$-Galactosidase production during sporulation in strains carrying a spoVAA : lac $Z$ gene fusion on the $\phi 105 \mathrm{~J} 20$ prophage. Strains lysogenic for $\phi 105 \mathrm{~J} 20$ and carrying no spo mutation $(O)$ or mutations in the spoIIIC $(\square)$, spoIIIF $(\square)$ or spoVB $(\boldsymbol{\Lambda})$ loci were induced to sporulate as described in Methods. At intervals, samples were taken and assayed for $\beta$-galactosidase activity.

\section{Effects of spo mutations on spoVAA : :lacZ expression}

The spoVAA : : lac $Z$ fusion, carried on the $\phi 105 \mathrm{~J} 20$ prophage, was transferred to each member of the series of spo mutant strains listed in Table 1 of the preceding paper (Errington \& Mandelstam, 1986), by selection for transduction of the phage-mediated chloramphenicol resistance. Each of the derivative strains was induced to sporulate, and samples were taken for assay of $\beta$-galactosidase at $t_{0}$ and $t_{4}$. The results (means of at least two independent experiments) are summarized in Table 2 . Strains with mutations in stage 0 and stage II loci all showed negligible $\beta$-galactosidase activities ( $<7 \%$ of the activity of the $\mathrm{Spo}^{+}$strain), with the exception of the spoIIB mutant, which had an activity somewhat greater than the basal level. The stage III loci were divided into two groups: (a) spoIIIA, spoIIIB and spoIIIE mutants showed negligible $\beta$ galactosidase activities ( $<7 \%$ of the activity of the $\mathrm{Spo}^{+}$strain); $(b)$ spoIIIC, spoIIID and spoIIIF mutants made appreciable amounts of the enzyme ( $>19 \%$ of the activity of the $\mathrm{Spo}^{+}$strain). None of the mutations in 'later' loci prevented synthesis of appreciable amounts of $\beta$ galactosidase. Strains with mutations in the spoIVC, spoIVD and particularly the spoVE loci seemed to over-express $\beta$-galactosidase in comparison with the $\mathrm{Spo}^{+}$control strain.

Since phage $\phi 105 \mathrm{~J} 20$ carries, in addition to the spoVAA : : lac $Z$ fusion, an intact, wild-type copy of the spoIIA locus, it was not possible to test the effects of spoIIA mutations using this system. Instead, DNA from a strain carrying a chromosomal spoVAA::lacZ gene fusion was transferred into recipient strains carrying mutations in spoIIA. Chloramphenicol-resistant transformants possessing the characteristic SpoIIA ${ }^{-}$phenotype were used for $\beta$-galactosidase assays.

In the preceding paper (Errington \& Mandelstam, 1986) it is shown that in strains carrying mutations in the spo0J, spoIIIF and spoVIC loci there is delayed expression of the spoIIAA : :lacZ gene fusion. More detailed time course studies for $\beta$-galactosidase expression from the 
Table 2. Effects of spo mutations on the production of $\beta$-galactosidase by the spoVAA : :lacZ gene fusion during sporulation

Phage $\phi 105 \mathrm{~J} 20$, carrying a spoVAA : : lac $Z$ gene fusion, was transduced into a series of spo mutant strains (see Table 1 of accompanying paper, Errington \& Mandelstam, 1986). Each transductant in turn was induced to sporulate and samples were taken for assay of $\beta$-galactosidase. Results shown are the mean activities (as percentages of the wild-type activity) at $t_{4}$, with the number of independent determinations in parentheses. The wild-type $\mathrm{Spo}^{+}$strain containing a $s p o V A A::$ lac $Z$ fusion (SG37) produced 0.80 units $\beta$-galactosidase ( $\mathrm{ml}$ culture) ${ }^{-1}$ at $t_{4}$ (mean of five determinations). An isogenic strain (MB75) containing no lacZ fusion produced $4.1 \%$ of the wild-type activity in a control experiment.

\begin{tabular}{ccccccccc} 
& \multicolumn{7}{c}{$\beta$-Galactosidase activity (\% of wild-type activity) } \\
\cline { 2 - 9 } Mutated locus & 0 & \multicolumn{1}{c}{$I I$} & $I I I$ & $I V$ & $V$ & $V I$ & ger \\
$A$ & $2.6(2)$ & $4.9(2)^{*}$ & $2.5(2)$ & $53(3)$ & $83(2)$ & $84(4)$ & \\
$B$ & $2.8(2)$ & 15 & $(3)$ & $3.1(2)$ & $31(3)$ & $80(4)$ & $79(3)$ & \\
$C$ & & & 19 & $(6)$ & $160(4)$ & $110(2)$ & $31(2)$ & \\
$D$ & $4.0(2)$ & $3.5(3)$ & 65 & $(2)$ & $150(3)$ & $50(5)$ & & \\
$E$ & $5.0(2)$ & $6.3(2)$ & $6.0(3)$ & $100(2)$ & $300(2)$ & & $98(2)$ \\
$F$ & $5.6(2)$ & & 31 & $(8)$ & $79(4)$ & $75(2)$ & & \\
$G$ & $5.0(2)$ & $6.1(3)$ & & & $58(3)$ & & & \\
$H$ & $4.3(2)$ & & & & $50(2)$ & & \\
$J$ & $6.0(2)$ & & & & $51(2)$ & &
\end{tabular}

\footnotetext{
* Result for spoIIAA mutation; determined in a strain carrying a chromosomal spoVAA : :lacZ fusion (see Results).

$\dagger$ Result for spoIIAC mutation; determined in a strain carrying a chromosomal spoVAA : : lacZ fusion (see Results).
}

spoVAA : :lacZ gene fusion in the presence of these and other mutations were done to determine whether similar delays in expression could be identified. Activity was not detected in a spo0J mutant but a delay in expression of approximately $1 \mathrm{~h}$ was found in strains carrying mutations in the spoIIIC, spoIIIF, spoVB and spoVIC loci. The times of expression in some of these mutant strains are shown in Fig. 3.

\section{Forespore-specific expression of the spoVAA : : lac Z fusion}

$\beta$-Galactosidase production in strain SG37 peaks at about $t_{4}$ (Fig. 2). On the assumption that spoVA is expressed in the spore compartment (see Introduction), one could explain the apparent fall in activity after $t_{4}$ by the onset of toluene-resistance that occurs at this time (Jenkinson et al., $1980)$. Since the $\beta$-galactosidase assay depends upon toluene permeabilization of the cell, the development of toluene-resistance in the spore would lead to an apparent fall in enzyme activity caused by failure of the substrate to enter the spore compartment. If this were so, germination, which restores toluene-sensitivity, ought to effect an increase in the measurable activity. Accordingly, strain SG37, a $\mathrm{Spo}^{+}$strain carrying the spoVAA : :lacZ fusion on the $\phi 105 \mathrm{~J} 20$ prophage, was induced to sporulate and samples were taken at $t_{6}$ and at $t_{22}$. The cells were harvested, and portions were separated into spore and mother cell fractions, each of which was then assayed for $\beta$-galactosidase both before and after treatment with germinants (see Methods). The frequency of germination was much lower in the $t_{22}$ spores than in the $t_{6}$ spores. This was understandable because cold-shocked spores at $t_{6}$ respond well to germinants (Dion \& Mandelstam, 1980), whereas more mature spores germinate efficiently only after heat shock (Powell \& Hunter, 1955). Heat-shock treatment was avoided since this might have caused inactivation of $\beta$-galactosidase. Nevertheless, treatment of both $t_{6}$ and $t_{22}$ spores with germinants led to substantial increases in $\beta$-galactosidase activity in all except the mother cell fractions (Table 3). Furthermore, most (70-80\%) of the $\beta$-galactosidase activity in the germinated samples was found in the spore fractions. These results strongly suggest that most of 
Table 3. Distribution of $\beta$-galactosidase activities in the forespore and mother cell fractions of sporulating cells containing a spoVAA : : lacZ gene fusion

Strain SG37 was induced to sporulate and samples were harvested at $t_{6}$ and at $t_{22}$. Various fractions were assayed $\beta$-galactosidase after incubation with $(+)$ or without $(-)$ germinant (see Methods). The percentage germination in the 'whole culture' samples, as determined by microscopic examination after treatment, was as follows: $t_{6}$ with germinant, $57 \%(74 / 124) ; t_{6}$ without germinant, $5 \%(6 / 117) ; t_{22}$ with germinant, $28 \%(39 / 119) ; t_{22}$ without germinant, $5 \%(5 / 103)$.

\begin{tabular}{|c|c|c|c|}
\hline \multirow[b]{2}{*}{ Fraction } & \multirow{2}{*}{$\begin{array}{c}\text { Germinant } \\
\text { added }\end{array}$} & \multicolumn{2}{|c|}{$\begin{array}{c}\beta \text {-Galactosidase activity } \\
\quad \text { (arbitrary units) }\end{array}$} \\
\hline & & $t_{6}$ & $t_{22}$ \\
\hline Whole culture & $\begin{array}{l}+ \\
-\end{array}$ & $\begin{array}{l}1.9 \\
1.0\end{array}$ & $\begin{array}{l}0.51 \\
0 \cdot 14\end{array}$ \\
\hline $\begin{array}{l}\text { Whole culture after cell } \\
\text { breakage (French pressure cell) }\end{array}$ & $\begin{array}{l}+ \\
-\end{array}$ & $\begin{array}{l}2 \cdot 1 \\
1 \cdot 5\end{array}$ & $\begin{array}{l}0.95 \\
0.20\end{array}$ \\
\hline $\begin{array}{l}\text { 'Mother cell fraction' } \\
\text { (supernatant) }\end{array}$ & $\begin{array}{c}+ \\
-\end{array}$ & $\begin{array}{l}0 \cdot 36 \\
0 \cdot 26\end{array}$ & $\begin{array}{l}0.082 \\
0.095\end{array}$ \\
\hline 'Spore fraction' (pellet) & $\begin{array}{l}+ \\
-\end{array}$ & $\begin{array}{l}1 \cdot 1 \\
0 \cdot 81\end{array}$ & $\begin{array}{l}0.31 \\
0.061\end{array}$ \\
\hline
\end{tabular}

the enzyme activity is in the spore compartment and that its detection by the standard assay is attenuated during development of the spore.

\section{Synthesis of spore coat proteins by spoVA mutants}

Since expression of the $\operatorname{spoVAA}:: l a c Z$ fusion gene begins relatively early in sporulation (about $t_{2 \cdot 5}$ ) and may be presumed to be spore specific, it was of interest to investigate the effect of spoVA mutations on later events that might be considered specific for spore development. Some, at least, of the spore coat proteins are likely to be synthesized specifically in the mother cell, since they form the outer layer of the mature spore (Jenkinson et al., 1981). The structure of the spore coat in spoVA mutants might therefore be indicative of the requirement for spoVA expression in the mother cell. Spore coat deposition in spoVA mutants appears normal as judged by electron microscopy (Piggot \& Coote, 1976). To investigate this further, strain 89.9 , a spoVA mutant, and a Spo ${ }^{+}$strain, 168 , were induced to sporulate. At $t_{9}$ the spores were harvested and the spore coat proteins were isolated and separated by SDS-PAGE. All of the major coat polypeptides described by Jenkinson et al. (1981) were present in both preparations (Fig. 4).

\section{DISCUSSION}

Expression of the spoVAA : :lacZ fusion gene begins at about $t_{2 \cdot 5}$ (Fig. 2), almost $2 \mathrm{~h}$ earlier than the phenotypic lesion of spoVA mutations is first manifested through the characteristic absence of dipicolinic acid (Errington \& Mandelstam, 1984). The product of the other wellcharacterized 'stage $\mathrm{V}$ ' locus, spoVG, is expressed even earlier than $\operatorname{spoVA}$, viz. within the first hour of sporulation (Rosenbluh et al., 1981). This further emphasizes the notion that the time at which a spo gene is expressed may precede by several hours the time at which the phenotype produced by mutations in the gene becomes evident (Wood, 1972; Jenkinson et al., 1980).

Expression of spoVA was blocked by mutations in all of the $s p o 0$ and spoII loci, and in some of the stage III loci (Table 2). Unexpectedly, mutations in spoIIIC, spoIIID and spoIIIF did not prevent spoVA : :lac $Z$ expression, although spoIIIC and spoIIIF mutations caused a delay of about $1 \mathrm{~h}$ in the appearance of $\beta$-galactosidase (Fig. 3). However, the phenotypic properties of these mutants, such as the appearance of clearly visible phase-grey spores, suggested that they might be more properly classified as stage IV mutants, as has been suggested previously for the mutation in the spoIIIC locus (Piggot \& Coote, 1976). The possible mis-classification of spoIIIF590 may be due to the delay in sporulation that it causes and that is evident both in the expression of spoVAA : : lac $Z$ and in the stage II lac $Z$ gene fusions described in accompanying papers (Errington \& Mandelstam, 1986; Clarke et al., 1986). A corresponding delay of induction 


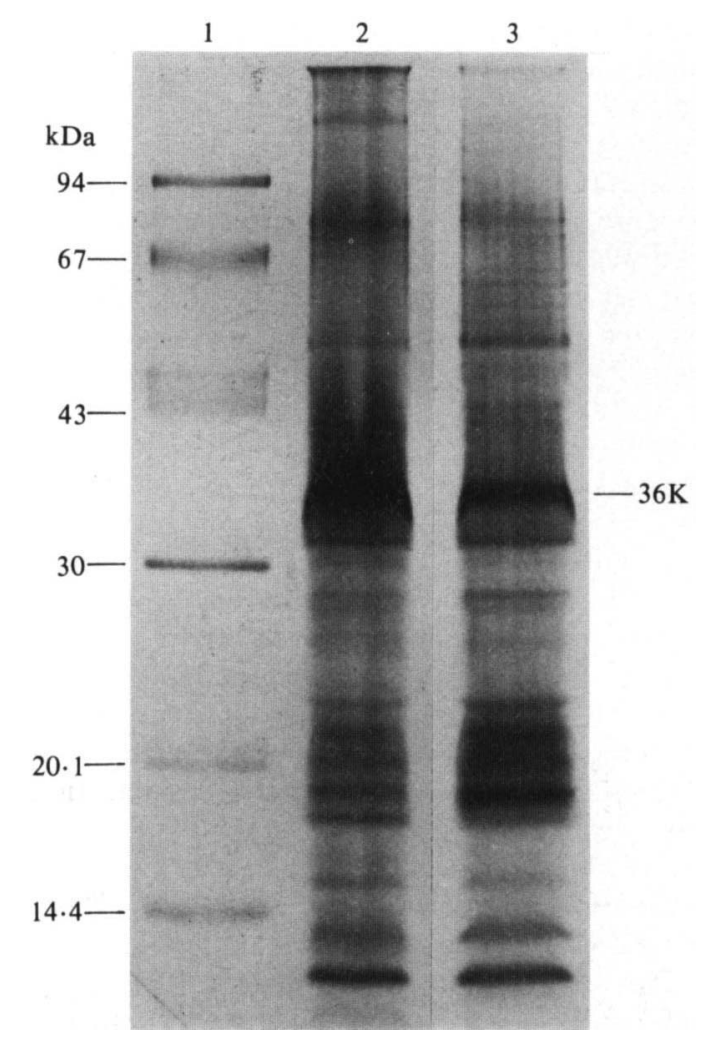

Fig. 4. SDS-PAGE patterns (stained with Coomassie blue) of spore coat proteins extracted from $t_{9}$ spores of strains 168 (track 2) and 89.9 (track 3 ). The position of ' $36 \mathrm{~K}$ ', the major late coat polypeptide of $36 \mathrm{kDa}$, is indicated. Track 1 contains standard proteins of known size.

could be responsible for the low glucose dehydrogenase activity at $t_{5}$, which formed part of the justification for placing spo-590 in a new locus, spoIIIF (Lamont \& Mandelstam, 1984).

Mutations in several other loci also caused a delay in $\operatorname{spoVAA}:: \operatorname{lac} Z$ expression. In one of these loci, spoVIC, mutations also delayed spoIIAA : :lacZ expression (Errington \& Mandelstam, 1986) and have previously been shown to cause a general delay in sporulation-associated events from an early stage (James \& Mandelstam, 1985). Of the other mutants, spoIIIC496 delayed expression of spoIID : :lacZ but not that of spoIIA : :lacZ, while spoVB delayed only spoVAA : :lac $Z$ expression. Thus, it seems that delay in the expression of sporulation specific genes may be relatively common in spo mutant strains. Mutation spoIIIC496, however, is an extensive chromosomal deletion ( $>5 \mathrm{kbp}$; A. L. Sonenshein, personal communication) that may encompass, in addition to an essential spo gene, several other genes of unknown function, the deletion of which might have secondary effects on sporulation.

Lencastre \& Piggot (1979) suggested on genetic grounds that the spoVA operon needs to be expressed in the forespore compartment for normal development to occur. Here we have presented more direct evidence that this compartment is in fact the site of expression of spoVA, but the results do not exclude the possibility that $\beta$-galactosidase is not detected in the mothercell because of rapid turnover. However, the identification of a spo locus (spoIIIC) that is expressed only in the mother cell compartment (Turner et al., 1986) should help to clarify this problem.

The fall in $\beta$-galactosidase activity after about $t_{4}$ was presumed to be due to the onset of toluene-resistance in the developing spore, since the effect was reversed by germination, which leads to almost immediate loss of resistance properties (Setlow, 1981). Some of the spo mutant strains that do not develop toluene resistance appeared to over-express $\beta$-galactosidase in 
comparison with $\mathrm{Spo}^{+}$strains (particularly spoIVC, spoIVD and spoVE mutants; Table 2). Several other mutants that did not over-express the enzyme, as measured at $t_{4}$, nevertheless showed continued accumulation of activity, in contrast to the subsequent sharp fall in activity seen in the wild-type and in strains such as the spoVA mutants that develop some resistance to toluene (results not shown). It therefore seems likely that toluene-resistance affects the detection of $\beta$-galactosidase in the spore. However, toluene treatment does not appear to be necessary for the detection of $\beta$-galactosidase by MUG when expressed from some spo genes. We have compared the measured activities in time-course experiments with and without toluene treatment, for expression from both the spoIIAA : :lac Z and spoVAA : :lacZ fusion genes in wildtype host cells (results not shown). The time course for spoIIA expression was similar in both cases, whereas the detected activity for the spoVA expression was almost negligible in the absence of toluene treatment. Furthermore, similar results were obtained even for late blocked toluene-sensitive spo mutants. It therefore appears that access of MUG into the developing spore is affected by factors, such as changes in permeability, that are distinct from those involved in resistance to toluene. Alternatively, it is possible that the biochemical state of the intact (i.e. non-toluene-treated) developing spore prevents enzymic cleavage of the substrate. In any case, the effect of toluene treatment on measured enzyme activity may provide a useful means of determining the compartment in which other spo::lac $Z$ fusion genes are expressed.

spoV $A$ expression begins at about $t_{2 \cdot 5}$, which corresponds approximately to the time at which the first sporulating cells in the population complete engulfment, i.e. reach stage III (Dawes et al., 1969). Since spoVA expression appears to be confined to the spore compartment, it would be interesting to look at the effect of spoVA mutations upon subsequent events in sporulation. Synthesis of the acid-soluble spore proteins and of glucose dehydrogenase are likely to be spore compartment events (reviewed by Setlow, 1981). Neither of these is prevented by spoVA mutations (Johnson et al., 1985; Errington \& Mandelstam, 1984), but both events occur at about the same time as spoVA is expressed, and therefore they might just precede expression of spoVA. Alternatively, all of these genes could be controlled by a common regulator. Synthesis of dipicolinic acid, a compound which is found in the spore (Murrell et al., 1969), normally begins at about $t_{4}$ but is prevented by mutations in spoVA (Errington \& Mandelstam, 1984). However, the distribution of this compound may be misleading since Andreoli et al. (1975) have suggested that dipicolinic acid synthetase, the enzyme responsible for dipicolinic acid synthesis, is located exclusively in the mother cell compartment. The synthesis and assembly of the spore coat proteins has been studied in detail (Jenkinson et al., 1981) and may be a good indicator of mother-cell-specific gene expression in $B$. subtilis. Synthesis of certain coat proteins begins at about $t_{2}$, whereas others begin to be synthesized later, mainly around $t_{3}$ or $t_{4}$. The proteins are deposited on the outside of the developing spore in a multi-layered structure, not following the order in which they are synthesized. One major coat protein, of $M_{\mathrm{r}} 36000$ ('36K' protein), characteristically begins to be synthesized very late, from about $t_{6}$, and it is a major component of the outer layer of the mature spore coat. A spoVA mutant strain produced spore coats indistinguishable from those of the wild-type (Fig. 4). Since even the synthesis of the ' $36 \mathrm{~K}$ ' polypeptide as late as $t_{6}$ is unaffected by mutations in the spoVA operon, it seems that expression or non-expression of this operon may have no effect on the sequential expression of sporulation loci in the mother cell. The results presented here raise the possibility that expression of spoVA may represent an early event in a spore specific line of gene expression that is at least partially independent of events in the mother cell.

We thank Ms G. Roberts for excellent technical assistance. This work was supported by the Science and Engineering Research Council. J.E. is the recipient of a Royal Society 1983 Research Fellowship.

\section{REFERENCES}

Andreoli, A. J., Saranto, J., Baecker, P. A., Suehiro, S., Escamilla, E. \& Steiner, A. (1975). Biochemical properties of forespores isolated from Bacillus cereus. In Spores VI, pp. 418-424. Edited by P. Gerhardt, R. N. Costilow \& H. L. Sadoff.
Washington, DC: American Society for Microbiology.

Clarke, S., Lopez-Diaz, I. \& Mandelstam, J. (1986). Use of lac $Z$ gene fusions to determine the dependence pattern of the sporulation gene spoIID in spo 
mutants of B. subtilis. Journal of General Microbiology 132, 2987-2994.

Dawes, I. W., KaY, D. \& Mandelstam, J. (1969). Sporulation in Bacillus subtilis. Establishment of a time scale for the morphological events. Journal of General Microbiology 56, 171-179.

Dion, P. \& MANDElstaM, J. (1980). Germination properties as marker events characterizing later stages of Bacillus subtilis spore formation. Journal of Bacteriology 141, 786-792.

ERRINGTON, J. (1984). Efficient Bacillus subtilis cloning system using bacteriophage $\phi 105 \mathrm{~J} 9$. Journal of Microbiology 130, 2615-2628.

ERRINGTON, J. (1986). A general method for fusion of the Escherichia coli lacZ gene to chromosomal genes in Bacillus subtilis. Journal of General Microbiology 132, 0000-0000.

ERrington, J. \& MANDELStaM, J. (1984). Genetic and phenotypic characterization of a cluster of mutations in the spoVA locus of Bacillus subtilis. Journal of General Microbiology 130, 2115-2121.

ERrington, J. \& Mandelstam, J. (1986). Use of a lacZ gene fusion to determine the dependence pattern of sporulation operon spoIIA in spo mutants of Bacillus subtilis. Journal of General Microbiology 132, 29672976.

Errington, J., Fort, P. \& Mandelstam, J. (1985). Duplicated sporulation genes in bacteria. Implications for simple developmental systems. FEBS Letters 188, 184-188.

ForT, P. \& ERrington, J. (1985). Nucleotide sequence and complementation analysis of a polycistronic sporulation operon, spoVA, in Bacillus subtilis. Journal of General Microbiology 131, 1091-1105.

Hames, B. D. (1981). An introduction to polyacrylamide gel electrophoresis. In Gel Electrophoresis of Proteins : a Practical Approach, pp. 1-91. Edited by B. D. Hames \& D. Rickwood. Oxford \& Washington, DC: IRL Press

Hranueli, D., Piggot, P. J. \& Mandelstam, J. (1974). Statistical estimate of the total number of operons specific for Bacillus subtilis sporulation. Journal of Bacteriology 119, 684-690.

JaMES, W. \& MANDELSTAM, J. (1985). spoVIC, a new sporulation locus in Bacillus subtilis affecting spore coats, germination and the rate of sporulation. Journal of General Microbiology 131, 2409-2419.

JENKINSON, H. F., KAY, D. \& MANDELSTAM, J. (1980). Temporal dissociation of late events in Bacillus subtilis sporulation from expression of the genes that determine them. Journal of Bacteriology 141, 793805.

Jenkinson, H. F., Sawyer, W. D. \& Mandelstam, J. (1981). Synthesis and order of assembly of spore coat proteins in Bacillus subtilis. Journal of General Microbiology 123, 1-16.

Johnson, W. C., MahleR, I., Phillips, K. \& Tipper, D. J. (1985). Transcriptional control of synthesis of acid-soluble proteins in sporulating Bacillus subtilis. Journal of Bacteriology 163, 543-551.

Kalnins, A., Otto, K., Ruther, U. \& Muller-Hil.t, B. (1983). Sequence of the lacZ gene of Escherichia coli. EMBO Journal 2, 593-597.

LAEMMLI, U. K. \& FAVRE, M. (1973). Maturation of the head of bacteriophage T4.I. DNA packaging events. Journal of Molecular Biology 80, 575-599.
LAMONT, I. L. \& MANDELSTAM, J. (1984). Identification of a new sporulation locus, spoIIIF, in Bacillus subtilis. Journal of General Microbiology 130, 12531261.

Lencastre, H. DE \& Piggot, P. J. (1979). Identification of different sites of expression for spo loci by transformation of Bacillus subtilis. Journal of General Microbiology 114, 377-389.

Murrell, W. G., Ohye, D. F. \& Gordon, R. A. (1969). Cytological and chemical structure of the spore. In Spores IV. Edited by L. L. Campbell. Washington, DC: American Society for Microbiology.

Nakayama, T., Irikura, M., Kurogi, Y. \& Matsuo, H. (1981). Purification and properties of RNA polymerases from mother cells and forespores of sporulating cells of Bacillus subtilis. Journal of Biochemistry 89, 1681-1691.

Piggot, P. J. \& COOTE, J. G. (1976). Genetic aspects of bacterial endospore formation. Bacteriological $R e$ views 40, 908-962.

Piggot, P. J., Moir, A. \& Smith, D. A. (1981). Advances in the genetics of Bacillus subtilis differentiation. In Sporulation and Germination pp. 29-39. Edited by H. S. Levinson, A. L. Sonenshein \& D. J. Tipper. Washington, DC: American Society for Microbiology.

Powell, J. F. \& Hunter, J. R. (1955). Spore germination in the genus Bacillus: the modification of germination requirements as a result of preheating. Journal of General Microbiology 13, 59-67.

Rosenbluh, A., Banner, C. D., Losick, R. \& FitzJAMES, P. C. (1981). Identification of a new developmental locus in Bacillus subtilis by construction of a deletion mutation in a cloned gene under sporulation control. Journal of Bacteriology 148, 341351 .

Savva, D. \& Mandelstam, J. (1984). Cloning of the Bacillus subtilis spoIIA and spoVA loci in phage $\phi 105 \mathrm{DI}$ : 1t. Journal of General Microbiology 130, 2137-2145.

SavVa, D. \& Mandelstam, J. (1985). Use of cloned spoIIA and spoVA probes to study synthesis of mRNA in wild-type and asporogenous mutants of Bacillus subtilis. In Molecular Biology of Microbial Differentiation, pp. 55-59. Edited by P. Setlow \& J. Hoch. Washington, DC: American Society for Microbiology.

Savva, D. \& Mandelstam, J. (1986). Synthesis of spoIIA and spoVA mRNA in Bacillus subtilis. Journal of General Microbiology 132, 3005-3011.

SETLOW, P. (1981). Biochemistry of bacterial forespore development and spore germination. In Sporulation and Germination, pp. 13-28. Edited by $\mathrm{H}$. S. Levinson, A. L. Sonenshein \& D. J. Tipper. Washington, DC: American Society for Microbiology.

TURner, S. M., ERrington, J. \& Mandelstam, J. (1986). Use of a lac $Z$ gene fusion to determine the dependence pattern of the sporlilation gene spoIIIC in spo mutants of Bacillus subtilis: a branched pathway of expression of sporulation operons. Journal of General Microbiology 132, 2995-3003.

WoOD, D. A. (1972). Properties and time of synthesis of alkali-soluble protein of the spore coat. Biochemical Journal 130, 505-514. 